\title{
TINJAUAN HUKUM LINGKUNGAN TERHADAP PENANGKAPAN KEPITING BERTELUR DIDUSUN MENCO KECAMATAN WEDUNG KABUPATEN DEMAK
}

\author{
Oleh \\ Pipit Fahri Wahyu Saputra
}

\begin{abstract}
ABSTRAK
Masyarkat Menco Kecamatan Wedung Kabupaten Demak yang sebagian besar berprofesi sebagai petani tambak dan nelayan tradisional yang masih menggantungkan hasil tangkapan dialam yang berupa kepiting untuk memenuhi kebutuhan hidup sehari-hari.Oleh karena itu penulis membahas mengenai Tinjaun Hukum Lingkungan Terhadap Penangkapan Kepiting Bertelur di Dusun Menco Kecamatan Wedung Kabupaten Demak.Adapun yang menjadi permasalahan menurut penulis dalam penelitian ini adalah : (1) Bagaimana dampak penangkapan kepiting bertelur dalam lingkungan hidup masyarakat Desa Menco? (2)Bagaimana tinjauan hukum lingkungan terhadap penangkapan kepiting bertelur?.

Tujuan penelitian ini adalah untuk menjelaskan dampak dari penangkapan kepiting bertelur dalam lingkungan hidup masyarakat Menco dan untuk menjelaskan mengenai tinjauan hukum lingkungan terhadap penangkapan kepiting bertelur

Tipe penelitian yang digunakan dalam penelitian ini adalah tipe penelitian yuridis sosiologis.Spesifikasi penelitian dalam penulisan ini bersifat deskriptif analitis.Analisis yang dipergunakan dalam penulisan skripsi ini adalah deskriptif analisis.

Berdasarkan hasil penelitian dan pembahasan mengenai eksistensi Peraturan Menteri Kelautan dan Perikanan Nomor 1 Tahun 2015 Tentang Pelarangan Penangkapan Lobster, Kepiting dan Rajungan dalam lingkup hidup masyarakat Menco Kecamatan Wedung Kabupaten Demak dapat menjawab permasalahan yang ada bahwa penangkapan kepiting yang dilakukan oleh masyarakat Menco tidak sesuai dengan yang sudah ditetapkan oleh Pemerintah melalui Peratutan Menteri Kelautan dan Perikanan Nomor 1 Tahun 2015 Tentang Pelarangan Penangkapan Lobster, Kepiting dan Rajungan. Dampak yang ditimbulkan dari penangkapan kepiting yang dilakukan oleh masyarakat Menco beragam dari ekonomi sampai populasi dari kepiting yang berada dialam bebas.Dapat disimpulkan bahwa kegiatan penangkapan kepiting yang dilakukan oleh masyarakat Menco baik nelayan maupun pemilik tambak tergolong
\end{abstract}


melanggar peraturan yang ada dan merugikan mayarakat itu sendiri terutama masyarakat Menco.

Kata Kunci : Hukum Lingkungan, Penangkapan, Kepiting Bertelur, Dampak.

\section{PENDAHULUAN}

Dusun Menco merupakan dusun yang mayoritas masyarakatnya sebagian besar bermata pencaharian sebagai nelayan dan juga adapula yang bermata pencaharian sebagai petani tambak.Hal tersebut dikarenakan letak Desa Menco berdekatan dengan daerah pesisir yang menjadikan masyarakat menco bermata pencaharian sebagai nelayan dan juga sebagai petani tambak.Dalam memenuhi kebutuhan sehari-hari masyarakat menco hanya menggantungkan hasil laut dan juga dari tambak, dimana hasil tersebut dapat dikatakan tidak menentu bahkan untuk mencukupi kebutuhan sehari-hari masyarakat menco terkadang hutang kepada pemodal ikan. Banyak sedikitnya hasil laut yang didapatkan oleh masyarakat menco ditentukan oleh kondisi alam, dimana pada saat cuaca buruk dapat dipastikan hasil tangkapan masyarakat menco baik dari laut maupun dari tambak akan menurun dikarenakan sebagian besar masyarakat Desa Menco tidak berani untuk pergi melaut.

Hasil tangkapan nelayan menco tidak hanya dipengaruhi oleh cuaca saja, terutama hasil dari
tambak.Dimana banyak sedikitnya hasil yang diperoleh dari tambak juga dipengaruhi oleh kualitas airnya, untuk sekarang ini nelayan menco beranggapan bahwa air laut maupun air yang berada didalam tambak sudah tidak begitu baik. Tambak yang dimiliki oleh masyarakat menco yang semula dapat diisi oleh berbagai jenis ikan maupun kerang-kerangan untuk sekarang ini hanya dapat diisi jenis ikan saja sedangkan untuk kerangkerangan dapat dikatakan sudah tidak bisa. Salah seorang masyarakat menco yang bernama bapak Musle yang bermata pencaharian sebagai nelayan sekaligus sebagai petani tambak berpendapat untuk tambak yang diisi kerang-kerangan untuk sekarang ini sudah tidak begitu menguntungkan karena untuk 1ton bibit kerang-kerangan yang disebar ditambak maksimal hanya bisa dipanen sebanyak 2-3 ton saja, padahal sebelumnya bisa sampai 4 ton kerang yang dapat dipanen.

Khususnya untuk tangkapan hasil laut yang berupa kepiting sendiri masyarakat Menco sudah mengetahui bahwa dalam penangkapannya ada syarat-syarat yang harus ditaati khususnya untuk para nelayan, namun nelayan 
maupun petani tambak yang melakukan tangkapan kepiting juga masih banyak yang mengabaikan aturan yang sudah ditetapkan oleh Pemerintah, dimana mereka beralasan untuk memenuhi kebutuhan hidup dan juga mereka berpikiran bahwa tindakan yang dilakukannya tidak akan membuat persediaan kepiting dialam habis. Mereka menyatakan bahwa cara penangkapan mereka masih menggunakan cara yang tradsional dimana nelayan Menco menggunakan alat tangkap bernama banjur(bubu), jebak (pancing), dan jaring.

Hasil yang didapatkan juga beragam jumlah dan bentuknya, dimana ada beberapa faktor yang mempengaruhi hal tersebut antara lain oleh alat yang digunakan kedua tata letak alat yang digunakan itu sendiri dan juga musim.

Jika dilihat dari alat yang digunakan nelayan Menco dapat dikatakan tidak melanggar namun jika dilihat dari ukuran yang ditangkap nelayan menco dapat dikatakan sudah melakukan pelanggaran, dimana hasil tangkapan yang didapatkan jauh dari yang diperintahkan oleh Undang-Undang. Dalam Undang-Undang Nomor 45 Tahun 2009 Tentang Perubahan Atas Undang-Undang Nomor 31 Tahun 2004 Tentang Perikanan didalam pasal 7 ayat 1 yang berbunyi dalam rangka mendukung kebijakan pengelolaan sumber daya ikan,
Menteri menetapkan: huruf q yang berbunyi ukuran atau berat minimum jenis ikan yang boleh ditangkap.

Sedangkan hasil tangkapan kepiting yang didapat oleh nelayan menco dapat dikatakan ukurannya dibawah ketentuan Peraturan yang sudah ditetapkan dalam hal ini Peraturan Menteri Kelautan dan Perikanan, sedangkan ukuran kepiting yang didapatkan dengan ukuran antara $7-10 \mathrm{~cm}$ untuk ukuran $10 \mathrm{~cm}$ sudah termasuk kepiting dengan kualitas terbaik dimana harga jualnya cukup tinggi dibandingkan dengan ukuran kepiting yang lainnya. Tidak hanya sampai diukuran saja nelayan Menco juga menangkap kepiting dalam kondisi bertelur baik dalam ukuran kecil maupun dalam ukuran yang besar. Jika mengacu pada PERATURAN MENTERI KELAUTAN DAN PERIKANAN NO 1 TAHHUN 2015 Tentang PENANGKAPAN LOBSTER, KEPITING, DAN RAJUNGAN yang berada pada pasal 4 yang berbunyi setiap orang yang menangkap lobster, kepiting dan rajungan wajib:

a. Melepaskan lobster, kepiting, dan rajungan dalam kondisi bertelur sebagaimana dimaksud dalam pasal 2 dan / atau dengan ukuran yang tidak sesuai dengan ketentuan sebagaimana dimaksud dalam pasal 3 ayat (1) jika masih dalam keadaan hidup.

b. Melakukan pencatatan lobster, kepiting dan rajungan dalam 
kondisi bertelur sebagaimana dimaksud dalam pasal 2 dan/atau dengan ukuran yang tidak sesuai dengan ketentuan sebagaimana dimaksud dalam pasal 3 ayat (1) yang tertangkap dalam keadaan mati dan melaporkan kepada Direktur Jendral melalui Kepala pelabuhan pangkalan sebagaimana tercantum dalam Surat Izin Penangkapan Ikan.

Jika dilihat dari Peraturan yang diatas maka nelayan Menco wajib melakukan tindakan pelepasan dan juga pencatatan yang kemudian dilaporkan kepada Direktur Jendral Kepala Pelabuhan pangkalan, dimana tindakan tersebut untuk mejaga persediaan kepiting yang berada dialam bebas. Kenyataannya nelayan Menco tidak melakukan hal tersebut, bisa dikatakan dikarenakan faktor ekonomilah yang mendorong pelanggaran tersebut dan juga nelayan menco beryakinan tindakan yang dilakukannya tidak akan menghabiskan persediaan dialam karena nelayan Menco masih menggunakan cara tradisional dan juga menangkap secukupnya untuk memenuhi kebutuhan hidup seharihari. Nelayan Menco juga tidak setuju jika tindakannya akan mempengaruhi ekosistem dalam hal ini jumlah persediaan kepiting dialam. Memang dalam penangkapan terkadang nelayan Menco mengalami kesulitan dalam mendapatkan kepiting, namun hal tersebut bukan dikarenakan jumlah kepiting menurun melainkan hal tersebut dipengaruhi oleh musim. Jika penangkapan dilakukan antara bulan Maret sampai Mei nelayan Menco akan mudah untuk mendapatkan kepiting, namun akan beda ceritanya jika penangkapan dilakukan selain bulan tersebut maka nelayan Menco akan mengalami Kesulitan untuk mendapatkan kepiting dan jumlahnya hanya hitungan per ekor sampai $1 \mathrm{~kg}$ (satu kilogram) saja.

Masyarakat Menco akan berhenti melakukan penangkapan kepiting terutama dalam kondisi bertelur jika pemerintah memberikan pelatihan mengenai cara mengembangbiakan kepiting agar nelayan Menco tidak lagi menangkap dialam dan juga kebutuhan hidup sehai-hari tetap tercukupi bahkan meningkat. Hal inilah yang membuat penulis untuk melakukan penelitian tentang "TINJAUAN HUKUM LINGKUNGAN TERHADAP PENANGKAPAN KEPITING BERTELUR DIDUSUN MENCO KECAMATAN WEDUNG KABUPATEN DEMAK”.

\section{TINJAUAN PUSTAKA}

Tinjauan hukum lingkungan terhadap penangkapan kepiting bertelurdalam penelitian ini menggunakan Teori Perlindungan Hukum dan Teori Keadilan.Teori Perlindungan Hukum adalah teori yang mengkaji dan menganalisis tentang wujud atau 
bentuk atau tujuan perlindungan, subjek hukum yang dilindungi serta objek perlindungan yang diberikan oleh hukum kepada subyeknya.Teori Perlindungan Hukum merupakan salah satu teori yang sangat penting untuk dikaji oleh karena fokus kajian pada teori ini pada perlindnungan hukum yang diberikan kepada masyarakat. Secara etimologis perlindungan hukum menurut Satjipto Rahardjo diartikan sebagai memberikan pengayoman terhadap hak asasi manusia (HAM) yang dirugikan orang lain dan perlindnngan itu diberikan kepada masyarakat agar dapat menikmati semua hak-hak yang diberikan oleh hukum.

Dalam Teori Keadilan, Makna keadilan hakikatnya bukan terbatas pada definisi atau konsep dalam kaitannya dengan hukum alam (the natural law), tetapi lebih pada soal praktis. Keadilan memiliki ragam makna menyebabkan banyak keragaman dalam definisinya. Menurut Leon Petrazycki keadilan adalah fenomena yang konkrit yang dapat ditangkap melalui penelitian intuisi, sementara menurut Gunawan Setiardi keadilan adalah dalam arti subjektif suatu kebiasaan baik jiwa yang mendorong manusia dengan kemauan tetap dan terus menerus untuk memberikan kepada setiap orang apa yang menjadi haknya.

\section{Lingkungan Hidup}

Lingkungan hidup adalah kesatuan ruang dengan semua benda, daya, keadaan, dan mahluk hidup, termasuk manusia dan perilakunya, yang mempengaruhi alam itu sendiri, kelangsungan perikehidupan dan kesejahteraan manusia serta mahluk hidup lain.

Menegenai pengertian lingkungan hidup, menurut ketentuan pasal 1 butir 1 Undang-Undang Nomor 32 tahun 2009 Tentang Perlindungan dan Pengelolaan Lingkungan Hidup, dijelaskan bahwa lingkungan hidup adalah kesatuan ruang dengan semua benda, daya, keadaan, dan mahkluk hidup, termasuk manusia dan perilakunya, yang mempengaruhi alam itu sendiri, kelangsungan perikehidupan, dan kesejahteraan manusia serta mahkluk hidup lainnya.

Faktor-faktor lingkungan dalam ekologi terbagi menjadi dua, yaitu meliputi lingkungan abiotik (segala apa yang ada dalam lingkungan sekitar mahkluk hidup yang berupa benda mati, seperti tanah dengan senyawa yang terkandung didalamnya, air, udara maupun sinar matahari). Lingkungan yang lain adalah lingkungan biotik yaitu segala apa yang ada yang berupa organisme yang ada disekitar mahkluk hidup. Berdasar uraian diatas dapat diuraiakan jenis-jenis lingkungan hidup yang terdiri dari lingkungan fisik dan lingkungan sosial. 


\section{Unsur-Unsur Lingkungan Hidup}

Lingkungan hidup pada dasarnya memiliki unsur-unsur yang dapat dibedakan menjadi 3 (tiga) yaitu :

a. Unsur Hayati (Biotik)

Unsur hayati (biotik) yaitu unsur lingkungan hidup yang terdiri dari mahkluk hidup, seperti manusia, hewan, tumbuhtumbuhan, dan jasad renik.Jika kalian berada di kebun sekolah, maka lingkungan hayatinya didominasi oleh tumbuhan.Tetapi jika berada didalam kelas, maka lingkungan hayati yang dominan adalah teman-teman atau sesama manusia.

b. Unsur Sosial Budaya

Unsur sosial budaya, yaitu lingkungan sosial dan budaya yang dibuat manusia yang merupakan sistem nilai, gagasan, dan keyakinan dalam perilaku sebagai mahkluk sosial. Kehidupan masyarakat dapat menacapai keteraturan berkat adanya sistem nilai dan norma yang diakui dan ditaati oleh segenap anggota masyarakat.

c. Unsur fisik (abiotik)

Unsur fisik (abiotik), yaitu unsur lingkungan hidup yang terdiri dari benda-benda tidak hidup, seperti tanah, air, uadara, iklim, dan lainlain.Keberadaan lingkungan fisik sangat besar peranannya bagi kelangsungan hidup segenap kehidupan di bumi. Jika air tidak ada lagi di muka bumi atau udara yang dipenuhi asap, tentu saja kehidupan di muka bumi tidak akan berlangsung secara wajar. Akan terjadi bencana kekeringan, banyak hewan dan tumbuhan mati, perubahan musim yang tidak teratur, munculnya berbagai penyakit, dan lain-lain.

\section{Hukum Lingkungan}

Istilah hukum lingkungan merupakan terjemahan dari beberapa istilah,yaitu "Enviromental Law" dalam bahasa inggris "Millieeurecht" dalam bahasa Belanda "Lenvironnment" dalam bahasa jerman.

Hukum lingkungan mempunyai 2 (dua) dimensi, yaitu yang pertama adalah ketentuan tentang tingkah laku masyarakat, semuanya bertujuan supaya anggota masyarakat dihimbau bahkan kalau perlu dipaksa memenuhi hukum lingkungan yang tujuannya memecahkan masalah lingkungan.Yang kedua adalah dimensi memberi hak, kewajiban, dan wewenang badan-badan pemerintah dalam mengelola lingkungan.

\section{Ekologi}

Ekologi adalah ilmu pengetahuan tentang hubungan antara organisme dan lingkungannya.Istilah ini pertama kali dikemukakan Reiter pada tahun 1865.Kata ini merupakan fokus mendasar dari ekologi yang 
membedakannya dari ilmu-ilmu biologi lainnya.Setelah Reiter memperkenalkan istilah tersebut, muncul kemudian ilmu ekologi.

\section{Kegiatan Manusia dan Sumber Daya Ikan}

Kerusakan lingkungan hidup banyak disebabkan oleh dominan kegiatan manusia. Menurut HomerDixon (1993), kegiatan manusia dapat menyebabkan kerusakan lingkungan atau kelangkaan sumber daya ikan dalam tiga cara. Pertama, kegiatan manusia dapat menyebabkan penurunan jumlah dan kualitas sumberdaya ikan, terutama jika sumberdaya dieksploitasi dengan tingkat kecepatan yang melebihi daya pulihnya.Kedua, penurunan atau kelangkaan sumberdaya ikan disebabkan oleh alat penangkapan ikan yang menyebabkan tangkap lebih (overfishing). Dengan bertambahnya penduduk dan menurunnya sumber daya ikan akan mempengaruhi pendapatan para nelayan dan menimbulkan kerugian bagi negara dan kepentingan nelayan sendiri. Hal ini berarti pemanfaatan sumber daya ikan melebihi regenerasi ikan itu sendiri. Ketiga, akses terhadap lingkungan sumberdaya ikan yang tidak seimbang juga akan menyebabkan banyak persoalan. Ketiga faktor kegiatan manusia di atas dapat terjadi secara sendiri-sendiri atau dalam kombinasi (Mitchel, B.Setiawan, Rahmi, 2010: 9-10).Ketiga kegiatan faktor tersebut merupakan kegiatan manusia yang tidak memperhatikan keberlanjutan sumber daya ikan.

Dalam keberlanjutan sumber daya ikan menuntut sebuah perubahan mendasar dalam kebijakan nasional, yang memberi prioritas pada kelestarian bentukbentuk kehidupan di laut, demi mencapai keberlanjutan sumber daya ikan.Sasaran utamanya bukan pembangunan itu sendiri, melainkan mempertahankan dan melestarikan sumber daya ikan dan seluruh kekayaan bentuk-bentuk kehidupan di laut.Hal ini harus menjadi komitmen politik pembangunan nasional, kalau tidak kehancuran sumber daya laut dan ancaman bagi kehidupan manusia di bumi ini semakin tidak serasi.Keberlanjutan sumber daya ikan atau kemenerusan sumber daya ikan merupakan upaya untuk tetap mempertahankan atau melestarikan fungsi lingkungan hidup sumber daya ikan.Pelestarian fungsi lingkungan hidup sumber daya ikan untuk menjaga agar lingkungan hidup (sumber daya ikan) ini tetap dapat menopang kehidupan baik generasi masa kini dan generasi masa mendatang.Generasi mendatang yang mendapatkan sumber daya ikan yang rusak sebagai akibat tindakan generasi masa kini dipandang dari aspek filosofis merupakan suatu ketidakadilan.

Ketidakadilan yang diciptakan oleh generasi masa kini merupakan perampasan hak atas 
lingkungan hidup yang baik dan sehat pada generasi masa mendatang.Keadaan tersebut menunjukkan ketidakharmonisan antara manusia dan lingkungan.Dasar filosofis lingkungan hidup salah satunya adalah eco developmentalis, bahwa hubungan antara manusia dan lingkungan hidup berbasis konsep bahwa lingkungan dan sumber daya ikan seharusnya dapat digunakan untuk meningkatkan keberadaban atau meningkatkan kesejahteraan manusia dan keberlanjutan sumber daya ikan.

Secara yuridis pengertian keberlanjutan lingkungan hidup (sumber daya ikan) tersirat dalam penjelasan Pasal 2 huruf b, UU No. 32 tahun 2009 tentang Perlindungan dan Pengelolalaan Lingkungan Hidup adalah "bahwa setiap orang memikul kewajiban dan tanggung jawab terhadap generasi mendatang dan terhadap sesamanya dalam satu generasi dengan melakukan upaya pelestarian daya dukung ekosistem dan memperbaiki kualitas lingkungan hidup”.

\section{Tinjauan Khusus}

\section{Penerapan Hukum Lingkungan Hidup Berdasarkan Undang- Undang}

Lingkungan hidup Indonesia karenanya harus dilindungi dan dikelola dengan baik berdasarkan asas tanggung jawab Negara, asas keberlanjutan, dan asas keadilan.Selain itu, pengelolaan lingkungan hidup harus dapat memberikan kemanfaatan ekonomi, sosial, dan budaya yang dilakukan berdasarkan prinsip kehati-hatian, demokrasi lingkungan, desentralisasi, serta pengakuan dan penghargaan terhadap kearifan lokal dan kearifan lingkungan.Perlindungan dan pengelolaan lingkungan hidup menuntut dikembangkannya suatu sistem yang terpadu berupa suatu kebijakan nasional perlindungan dan pengelolaan lingkungan hidup yang harus dilaksanakan secara taat asas dan konsekuen dari pusat sampai ke daerah.

\section{Kebijakan Pengelolaan Sumber Daya Perikanan Dengan Pendekatan Bio-Teknis}

Pertimbangan biologis harus menghindari kegagalan rekruitmen stok.Beberapa jenis alat tangkap seperti jaring sangat rawan terhadap penangkapan berlebih terhadap jenis ikan tertentu.Pertimbangan budaya sering sangat sukar, karena terkait dengan latar belakang kepercayaan, kebiasaan nelayan, preferensi etnik dan lain sebagainya.Faktor yang paling sulit dan memerlukan biaya tinggi adalah penegakan peraturan.

\section{Tinjauan Yuridis Penangkapan Kepiting Bertelur}

Kepiting merupakan salah satu komoditas perikanan yang hidup 
diperairan pantai, khususnya di hutan-hutan bakau (mangrove).Dengan sumber daya hutan bakau yang membentang luas diseluruh kawasan pantai nusantara, maka tidak heran jika Indonesia dikenal sebagai pengekspor kepiting yang cukup besar dibandingkan dengan Negara-negara produsen kepiting lainnya.

\section{METODE PENELITIAN}

\section{Tipe Penelitian}

Berdasrkan rumusan masalah dan tujuan penelitian, maka tipe pendekatan yang digunakan adalah tipe pendekatan yuridis sosiologis, yaitu menggunakan data sekunder kemudian dilanjutkan dengan data primer.Penelitian hukum sosiologis tetap bertumpu pada premis normatif, berbeda dengan penelitian ilmu-ilmu sosial yang hendak mengkaji hukum, dimana hukum ditempatkan sebagai dependent variable, oleh karena itu premis sosial yang menjadi tumpuannya. Pengumpulan data primer yang diperoleh secara langsung melalui penelitian dengan cara pengamatan (observasi) dan wawancara (interview) dengan responden atau narasumber yang berhubungan dengan permasalahan yang dibahas dalam penelitian ini.

\section{Spesifikasi Penelitian}

Spesifikasi dalam penelitian ini adalah deskriptif analitis, yaitu penelitian yang bertujuan mendeskripsikan mengenai penangkapan kepiting bertelur di Dusun Menco Kecamatan Wedung Kabupaten Demak, yang kemudian dikaitkan dengan teori teori hukum dan praktek pelaksanaan hukum positif yang menyangkut permasalahan diatas.

\section{Sumber Data}

Adapun sumber data yang dibutuhkan dalam rangka penelitia ini yaitu data primer dan data sekunder.

1. Data Primer yaitu keterangan atau fakta yang didapatkan penulis dari hasil kunjungan langsung ke lokasi penelitian.

2. Data Sekunder yaitu data yang diperoleh dari studi kepustakaan, berbagai literature, dan peraturan perundang- undangan. Sumber dari data sekunder yakni berupa :

a. UU No.32 Tahun 2009 tentang Perlindungan dan Pengelolaan Lingkungan Hidup.

b. UU No. 31 Tahun 2004 tentang Perikanan.

c. Peraturan Menteri Kelautan dan Perikanan Republik Indoneisa Nomor 1 Tahun 2015 Tentang Tentang PENANGKAPAN

LOBSTER (Panulirus spp.), KEPITING (Scylla spp.), 
DAN RAJUNGAN (Portunus pelagicus spp.).

d. Peraturan Menteri Kelautan dan Perikanan Republik Indonesia Nomor 56 Tahun 2016 Tentang LARANGAN PENANGKAPAN

DAN/ATAU PENGELUARAN

LOBSTER (Panulirus spp.), KEPITING (Scylla spp.), DAN RAJUNGAN (Portunus spp.) DARI WILAYAH NEGARA REPUBLIK INDONESIA.

\section{Metode Penyajian Data}

Bahan data yang diperoleh disajikan dalam bentuk uraian yang disusun secara sistematis dan logis. Yang dimaksud sistematis adalah keseluruhan data sekunder yang diperoleh akan dihubungkan satu dengan yang lainnya, disesuaikan dengan pokok permasalahan yang diteliti sehingga merupakan kesatuan yang utuh.

\section{Metode Analisis Data}

Analisis yang dipergunakan dalam penulisan skripsi ini adalah deskriptif analisis, yaitu suatu metode analisis yang dilakukan dengan cara mengumpulkansemua bahan yang diperoleh untuk kemudian ditelaah dan dianalisis berdasarkan peraturan perundangundangan dan teori yang berkaitan dengan permasalahan yang akan dibahas. Selanjutnya mengambil kesimpulan dengan menggunakan metode deduktif yaitu proses penarikan kesimpulan yang dimulai dari hal-hal yang bersifat umum menuju hal-hal yang bersifat khusus.

Metode analisis data yang digunakan dalam penelitian ini adalah analis secara kualitatif, dengan langkah-langkah sebagai berikut: Sebelum menganalisis data tersebut, terlebih dahulu diadakan pengorganisasian terhadap data sekunder dan data primer yang diperoleh dari para narasumber. Selanjutnya akan dianalisis dengan Undang- Undang No. 32 Tahun 2009 tentang Perlindungan dan Pengelolaan Lingkungan Hidup UU No. 31 Tahun 2004 tentang Perikanan.

\section{HASIL PENELITIAN DAN ANALISIS DATA}

\section{Gambaran Umum Dusun Menco Kecamatan Wedung Kabupaten Demak}

Dusun Menco termasuk salah satu dusun yang berada di wilayah Pemerintahan Desa Berahan Wetan yang terletak di Kecamatan Wedung Kabupaten Demak. Dusun Menco terdiri atas 5 Rukun Warga dimana pada Rukun Warga 5 memiliki jumlah penduduk yang paling besar diantara Rukun Warga yang lainnya, sedangkan pada Rukun Warga 7 memiliki jumlah penduduk yang pailing rendah dibandingkan dengan 
Rukun Warga lainnya yang berada di dusun Menco. Adapun jumlah pendudukmulai dari Rukun Warga I sampai dengan Rukun Warga IX total semua jumlah penduduk di Desa Berahan Wetan sebanyak delapan ribu seratus dua puluh lima(8.125) jiwa, sedangkan untuk Menco sendiri mulai dari Rukun Warga V samapai dengan Rukun Warga IX memiliki jumlah penduduk total sebanyak empat ribu Sembilan ratus enam puluh dua(4962) jiwa.

Penduduk

Desa

Berahandilihat mata pencaharian penduduk Desa Berahan Wetan Kecamatan Wedung Kabupaten Demak. Sebagian besar penduduk Desa Berahan Wetan Kecamatan Wedung Kabupaten Demak bekerja sebagai petani/ pekebun, namun untuk penduduk Menco sendiri khususnya mayoritas bermata pencaharian atau bekerja sebagai nelayan/ perikanan dimana dari jumlah seratus delapan puluh delapan (188) terdapat seratus empat puluh dua (142) penduduk menco sendiri bermata pencaharian sebagai nelayan/ perikanan. Tidak hanya bermata pencaharian sebagai nelayan melainkan terdapat juga penduduk menco bermata pencaharian atau bekerja sebagai kepala desa (1) satu orang, pelaut (1) satu orang, pedagang (20) dua puluh orang, buruh tani (7) tujuh orang, perangkat desa (1) satu orang, tukang jahit (2) dua orang, petani (10) sepuluh orang.
Gambaran Umum Penangkapan Kepiting di Menco Kecamatan Wedung Kabupaten Demak

Cara yang dilakukan untuk menangkap kepiting baik yang dilakukan oleh nelayan berbeda dengan yang dilakukan oleh petani tambak dimana petani tambak hanya menangkap kepiting yang masuk kedalam tambak yang dimilikinya kemudian air dalam tambak dikeluarkan dari tambak untuk memudahkan proses penangkapan kepiting yang berada didalam tambak tersebut.

Kepiting yang ditangkap oleh petani tambak atau kepiting yang berada didalam tambak merupakan kepiting dari alam liar yang ikut masuk dalam tambak saat pintu tambak dibuka dan terjebak dalam tambak saat air dalam tambak dikeluarkan kemuara sungai yang langsung menuju laut lepas.

Peralatan yang digunakan oleh nelayan Menco untuk menangkap kepiting dengan menggunakan alat-alat tradisional dimana untuk tetap menjaga kualitas kepiting dan juga menjaga keutuhan bagian-bagian dari tubuh kepiting yang sudah ditangkap dari alam tersebut.

\section{Dampak Penangkapan Kepiting Bertelur Dalam Lingkungan Hidup Masyarakat Menco \\ Masyarakat Menco menggantungkan kehidupannya hanya dari penangkapan kepiting}


saja, dimana mayoritas masyarakat Menco mengambil kepiting dari alam baik yang berukuran kecil maupun yang dalam kondisi bertelur. Penangkapan kepiting yang dilakukan oleh masyarakat Menco dapat dikatakan sudah masif karena sudah dilakukan turun temurun, apabila hal ini dibiarkan terus menerus akan memiliki dampak yang dapat merugikan masyarakat Menco itu sendiri. Dampak yang akanditimbulkan dapat berupa dari segi ekonomi, dari segi lingkungan maupun dari segi masyarakatnya itu sendiri.

Dampak yang sudah terjadi ini harus menjadi perhatian baik Pemerintah maupun masyarakat Menco itu sendiri karena dampak ini akan memiliki pengaruh yang cukup luas terutama dari segi perekonomian masyarakat Menco itu sendiri karena masyarakat Menco sudah terlalu lama menggantungkan mata pencaharian kepada penangkapan kepiting itu saja dengan kata lain masayarakat Menco tidak memiliki keahlian lain untuk memenuhi kebutuhan sehari- hari.

\section{Tinjauan Hukum Lingkungan Terhadap Penangkapan Kepiting Bertelur}

Kegiatan penangkapan kepiting yang dilakukan oleh masyarakat Menco yang terdiri dari nelayan dan petani tambak dapat dikatakan sebagai kegiatan perusakan alam, jika dilihat dari pengertian perusakan dalam pasal 1 ayat (16) UU Nomor 32 tahun 2009 tentang Perlindungan dan Pengelolaan Lingkungan Hidup yang berbunyi perusakan lingkungan hidup adalah tindakan orang yang menimbulkan perubahan lansung atau tidak langsung terhadap sifat, fisik, kimia, dan/ atau hayati lingkungan hidup sehingga melampaui kriteria baku kerusakan lingkungan hidup.

\section{Dampak Penangkapan Kepiting Bertelur Dalam Lingkungan Hidup Masyarakat Menco}

Sebagaimana telah diuraikan sebelumnya bahwa masyarakat Menco sebagian besar bekerja sebagai nelayan dan petani tambak.Para nelayan dan petani tambak telah menjalankan pekerjaannya secara turun temurun sejak dahulu.Keadaan nelayan dan petani tambak sebagaimana kehidupan pada masyarakat pesisir umumnya selalu menghadapi berbagai permasalahan yang menyebabkan kemiskinan.Pada umumnya para nelayan dan petani tambak menggantungkan hidupnya dari hasil penangkapan dialam dan hasil dari tambak yang dimiliki para petani tambak.Mayoritas nelayan dan petani dampak memiliki tingkat pendidikan yang rendah dan keterampilan berusaha yang sangat terbatas, sehingga menjadi nelayan dan petani tambak adalah pilihan utama. 


\section{Dampak Positif}

1. Penangkapan kepiting yang dilakukan oleh masyarakat Menco secara tradisional berdampak postif terhadap lingkungan karena alat yang digunakan oleh masyarakat Menco dalam kasus ini adalah nelayan dan Petani tambak tidak memiliki unsur merusak lingkungan dan habitat kepiting yang berupa hutan mangrove.

2. Penangkapan kepiting baik dalam kondisi bertelur maupun yang tidak bertelur secara ekonomi dapat membantu kebutuhan sehari-hari nelayan dan petani tambak Menco. Dari segi ekonomi kepiting yang dalam kondisi bertelur saja pada saat ditangkap sangat membantu perekonomian dari nelayan dan petani tambak karena harga $(1 \mathrm{~kg})$ satu kilogram kepiting dalam kondisi bertelur dapat mencapai harga Rp 155.000. Sedangkan kepiting dalam kondisi yang tidak bertelur atau masih kecil mencapai harga sebesar Rp55.000 per kilogramnya.

\section{Dampak Negatif}

1. Untuk jumlah ataupun ukuran kepiting yang ditangkap oleh masyarakat Menco (nelayan dan Petani tambak) baik dalam kondisi bertelur ataupun dalam kondisi tidak bertelur dalam jangka panjang mengakibatakan kelangkaan kepiting dialam bebas, hal ini dikarenakan nelayan dan petani tambak Menco setiap hari melakukan penangkapan kepiting tanpa memperhatikan jumlah, kondisi kepiting itu sendiri dan tidak memperhatikan musim tangkap. Nelayan dan petani tambak setiap hari dapat menangkap kepitingper orang mampu menangkap minimal 2-3kg.

2. Area atau wilayah penangkapan mengalami perubahan yang semula hanya didekat pemukiman atau didekat warga untuk sekarang penangkapan harus ditempuh dengan waktu kurang lebih 20menit dengan kata lain penangkapan kepiting yang dilakukan oleh masyarakat Menco berdampak pada wilyah atau area penangkapan dan membuat jumlah populasi kepiting dialam semakin menurun bahkan jika dibiarkan terus menerus kepiting dialam akan habis untuk selamnya.

\section{Tinjauan Hukum Lingkungan Terhadap Penangkapan Kepiting Bertelur}

Jika melihat isi pasal tersebut tindakan yang dilakukan oleh nelayan dan petani tambak dalam menangkap kepiting telah melanggar PERMEN KP NO 1 tahun 2015 tentang Pelarangan Penangkpan Lobster, Kepiting dan Rajungan. Nelayan Menco jika tetap melakukan 
pelanggaran dapat dikenakan sanksi administrasi maupun sanksi pidana dimana sanksi administrasi yang tertuang dalam pasal 4 Permen KP Nomor 1 tahun 2015 yang berbunyi :

Setiap orang yang menangkap lobster, kepiting dan rajungan wajib melepaskan lobster, kepiting, dan rajungan dalam kondisi bertelur sebagaimana dimaksud dalam pasal 2 dan/ atau dengan ukuran yang tidak sesuai dengan ketentuan sebagaimana dimaksud dalam pasal 3ayat 1 jika masih dalam keadaan hidup.

\section{PENUTUPAN}

\section{Kesimpulan}

Berdasarkan hasil penelitian dan pembahasan mengenai tinjauan hukum lingkungan terhadap penangkapan kepiting bertelur di Dusun Menco Kecamatan Wedung Kabupaten Demak dapat disimpulkan :

1. Dampak Penangkapan kepiting bertelur bagi lingkungan masyarakat Menco menimbulkan dampak negatif yang berupa akan menurunnya jumlah populasi kepiting dialam bebas dikarenakan setiap harinya nelayan dan pemiliki tambak melakukan penangkapan kepiting satu nelayan maaupun satu pemilik tambak dapat menangkap kepiting minimal 3kg setiap harinya.
2. Tinjauan hukum lingkungan terhadap penangkapan kepiting bertelur berdasarkan pasal 2 dan 3 PERMEN KP No 1 tahun 2015 Tentang Pelarangan Penangkapan Lobster, Kepiting dan Rajungan penangkapan yang dilakukan oleh masyarakat Menco telah melanggar aturan yang sudah ada dan berdasarkan pasal 100 UU No 31 Tahun 2004 Tentang Perikanan Pemerintah dapat mengenakan sanksi pidana berupa pidana denda maksimal Rp 250.000.000.00 kepada siapapun pihak termasuk masyarakat Menco itu sendiri

\section{Saran}

Pemerintah Kabupaten Demak perlu melakukan pelatihan terhadap bagaimana cara mengembangbiakan kepiting agar masayarakat Menco tidak lagi melakukan penangkapan kepiting dialam bebas dan dengan adanya pelatihan yang dilakukan oleh Pemerintah Kabupaten Demak dapat menjaga populasi kepiting dialam dan juga dapat mengurangi pelanggaran trhadap penangkapan kepiting itu sendiri yang terjadi di Menco.

Pemerintah Kabupaten Demak perlu memperhatikan sosialbudaya masyarakat pesisir terutama masyarakat Menco dan juga memperhatikan kemampuan SDM karena PERMEN KP No 1 Tahun 2015 Tentang Pelarangan 
Penangkapan Lobster, Kepiting dan Rajungan dilaksanakan begitu saja tanpa adanya pemberian solusi bagi masyarakat Menco maka pelanggaran tetap terjadi karena atas dasar sosial-budaya dan juga SDM yang mendukung mereka untuk melakukan pelanggran tersebut.

\section{DAFTAR PUSTAKA}

\section{Buku}

Danusaputro,Munajat. 1988.Hukum Lingkungan Buku 1 Umum. Bandung: Bina Cipta.

Hadjon, Philipus M. 1987. Perindungan Hukum Bagi Rakyat Indonesia, Surabaya: Bina Ilmu.

Hamzah, Andi. 2001.Penegakan Hukum Lingkungan, Jakarta: Sinar Grafika.

$\begin{array}{lr}\text { 2005.Penegakan } & \text { Hukum } \\ \text { Lingkungan.Jakarta: } & \text { Sinar } \\ \text { Grafika. } & \end{array}$

Hardati, Puji. 2015.Pendidikan Konservasi.Semarang: Pustaka utama.

Hardjosoemantri, Koesnadi. 2000.Hukum Tata Lingkungan. Yogyakarta: Gama Press.. 2001.
Hukum Tata Lingkungan. Yogyakarta: Gajah Mada University Press.

Haryon,Ismail. 2015. Analisis Hukum Terhadap Pencemaran Lingkungan Hidup Yang Ditimbulkan Oleh Perusahaan
Tepung Ikan Cv Bumi Indo Pati Kabupeten Pati.Skripsi.Fakultas Hukum:Semarang:

Husin, Sukanda. 2009.Penegakan Hukum Lingkungan Indonesia.Jakarta: Sinar Grfika.

Irawan, dan M. Suparmoko. 1999.EkonomikaPembangunan .Yogyakarta: BPFE, UGM.

Mertokusumo, Sudikno. 2014.Mengenal Hukum suatau Pengantar, Yogyakarta: Atmajaya.

Nurbani, Erlies S. danSalim, HS. 2013.Penerapan Teori Hukum pada Penelitian Tesis dan Disertasi. Jakarta: Radja Grafindo Persada.

Rahardjo,Satjipto. 2000.Ilmu Hukum. Bandung: Citra Aditya Bakti.

Rasyidi, Lili. 1988.Filsafat Hukum Bandung: Remaja Rosda Karya.

Rochmani. 2014.Hukum Lingkungan dan Penegakan Hukum. Semarang: Pustaka Magister.
Sastrawijaya,
A. Tresna. 2001.Pencemaran Lingkungan Hidup.Jakarta: Rineka Cipta.
Siahaan,N H T.2004. Hukum Lingkungan dan Ekologi Pembangunan. Jakarta: Erlangga.

Soedjono, 2001.Hukum dan Masalah Lingkungan Hidup. Bandung: Bina Cipta.

Soemarwoto, Otto. 1988.Analisa Dampak Lingkungan. 
Yogyakarta: Gajah Mada Universty Press.

Supardi, Bahrudin.2009. Berbakti Untuk Bumi.Bandung: Rosdakarya.

Susanti, Dyah O. 2015.Penelitian Hukum. Jakarta: Grafika.

Suteki. 2010.Rekontruksi Politik Hukum Hak Atas Air. Jawa Timur: Surya Pena Gemilang.

Jurnal, Artikel, Kertas Kerja

Rochmani, 2014."Penegakan Hukum

Yang Berorientasi Pada

Keberlanjutan Sumber Daya Ikan"

Jilid 21.

\section{Peraturan Perundang-Undangan}

Undang-Undang Dasar Negara Republik Indonesia 1945
Undang-Undang Nomor 32 Tahun 2009 Tentang Perlindnungan dan Pengelolaan Lingkungan Hidup
Undang-Undang Nomor 31 Tahun 2004 Tentang Perikanan
Peraturan Menteri Kelautan dan Perikanan Nomor 1 Tahun 2015 Tentang Pelarangan Penangkapan Lobster, Kepiting dan Rajungan

